\title{
Effects of Organic and Chemical Agriculture Systems on Arbuscular Mycorrhizal Fungi and Green Tomato Production in Calakmul, Mexico
}

\author{
Yuriko Pilar Cruz-Koizumi' ${ }^{1}$ José Armando Alayón-Gamboa1 ${ }^{*}$, Alejandro Morón-Ríos', \\ Jorge Castellanos-Albores ${ }^{2}$, Ana Aguilar-Chama ${ }^{3}$, Roger Guevara ${ }^{3}$ \\ ${ }^{1}$ Departamento de Conservación de la Biodiversidad, El Colegio de la Frontera Sur, Unidad Campeche, \\ Ciudad Industrial Lerma, Campeche, México \\ ${ }^{2}$ Departamento de Conservación de la Biodiversidad, El Colegio de la Frontera Sur, Unidad San Cristóbal de las \\ Casas, María Auxiliadora, San Cristóbal de las Casas, Chiapas, México \\ ${ }^{3}$ Red de Biología Evolutiva, Instituto de Ecología, A.C. El Haya, Xalapa, Veracruz, México \\ Email:*jalayon@ecosur.mx
}

How to cite this paper: Cruz-Koizumi, Y.P., Alayón-Gamboa, J.A., Morón-Ríos, A., Castellanos-Albores, J., Aguilar-Chama, A. and Guevara, R. (2018) Effects of Organic and Chemical Agriculture Systems on Arbuscular Mycorrhizal Fungi and Green Tomato Production in Calakmul, Mexico. Agricultural Sciences, 9, 1145-1167. https://doi.org/10.4236/as.2018.99080

Received: August 17, 2018

Accepted: September 16, 2018

Published: September 19, 2018

Copyright (c) 2018 by authors and Scientific Research Publishing Inc. This work is licensed under the Creative Commons Attribution International License (CC BY 4.0).

http://creativecommons.org/licenses/by/4.0/

\begin{abstract}
Organic agriculture is increasingly used as an alternative to conventional agriculture due to its positive impact on the health of ecosystems and agroecosystems. However, the outcome of organic agriculture in terms of the production of various crops remains uncertain due to the influence of many variables, rising questions about its advantages over conventional agriculture. This study assessed the impacts of organic agricultural system on arbuscular mycorrhizal (AM) fungi diversity in soil and green tomato (Physalis ixocarpa Brot. ex Horn) crop production. A field experiment was conducted using a random block design with five repetitions of the following treatments: a) Control (no fertilization, NF); b) Vermicompost use (OTV); c) OTV with vermicompost leaching (OTH); and d) Inorganic fertilization (CST). Throughout the crop cycle, soil samples were analyzed chemically, the relative growth rate (RGR) of the plants was measured, and the colonization and diversity of AM fungi were quantified in roots and soil; finally, above-ground, root biomass, and fruit production were measured. Organic fertilization (OTV, OTH) increased $(p<0.05)$ RGR $(10.47 \mathrm{~cm}$ OTV), AM colonization $(21.80 \%$ on OTV and $20.95 \%$ on OTH) and diversity ( 21 species on OTV and 28 species on OTH), compared to CST treatment (8.18 cm on RGR; $15.17 \%$ AM colonization, and 11 species). Some AM species were uniquely associated with organic matter, phosphorous, cation exchange capacity and bulk density of soil on the organic system; however, biomass production and fruit yield did not differ $(p>0.05)$. It is concluded that organic agriculture management is essential to promote a greater AM fungi diversity and fungi root coloniza-
\end{abstract}


tion. Plant-AM fungi interaction increases growth rates and it allows a similar tomato production compared with conventional agriculture.

\section{Keywords}

Vermicompost, Agrochemical Fertilization, Biodiversity

\section{Introduction}

Conventional agriculture applies large inputs of agrochemical products, especially inorganic fertilizers, to maintain global food production, affecting the health of natural and agricultural ecosystems, the human population, and jeopardizing the economy of resource-poor farmers [1]. Organic agriculture has been proposed as a safe and healthy alternative but the crop yield under this agricultural system is variable due to the influence and interaction of crop type, cultivation system, soil physicochemical characteristics and environmental variation [1] [2] [3]. Of these factors, soil quality constitutes a key factor in the results obtained with organic agriculture [4]. Physical soil and biological characteristics are improved with organic fertilizers, like vermicompost, which is the process of bio-oxidation and stabilization of organic matter in controlled conditions of the joint action of specific species of earthworm and microorganisms to accelerate the nutrients transformation [5] [6].

This kind of fertilization also increases the colonization of plant roots by arbuscular mycorrhizal (AM) fungi, their abundance and diversity [7]. This plant-fungi interaction plays a key role in the soil ecosystem services [8], because it maintains soil fertility and plant health. But, when intensive farming techniques are used in conventional agriculture systems these soil ecosystem services are degraded [9] [10].

The present study quantifies and compares the effects of vermicompost fertilization in the organic system against those obtained using chemical fertilizer in the conventional system on the changes in AM fungi diversity and intra root colonization, as well as the growth, yield and production of green tomato. We hypothesized that organic agricultural system, with vermicompost and leachate, increases AM fungi diversity and tomato plant growth, with similar yield as with agrochemicals.

\section{Materials and Methods}

\subsection{Site Description}

The study was conducted in El Chichonal community (Figure 1), $18^{\circ} 30^{\prime} 52^{\prime \prime} \mathrm{N}$ and $89^{\circ} 31^{\prime} 24^{\prime \prime} \mathrm{W}$, within the buffer zone of the Calakmul Biosphere Reserve (CBR) and in the municipality of Calakmul, Campeche, Mexico. There are more than 100 ejido communities in the area surrounding the CBR [7]. The land exhibits a plain topography with an altitude of 250 meters above sea level. The parent 


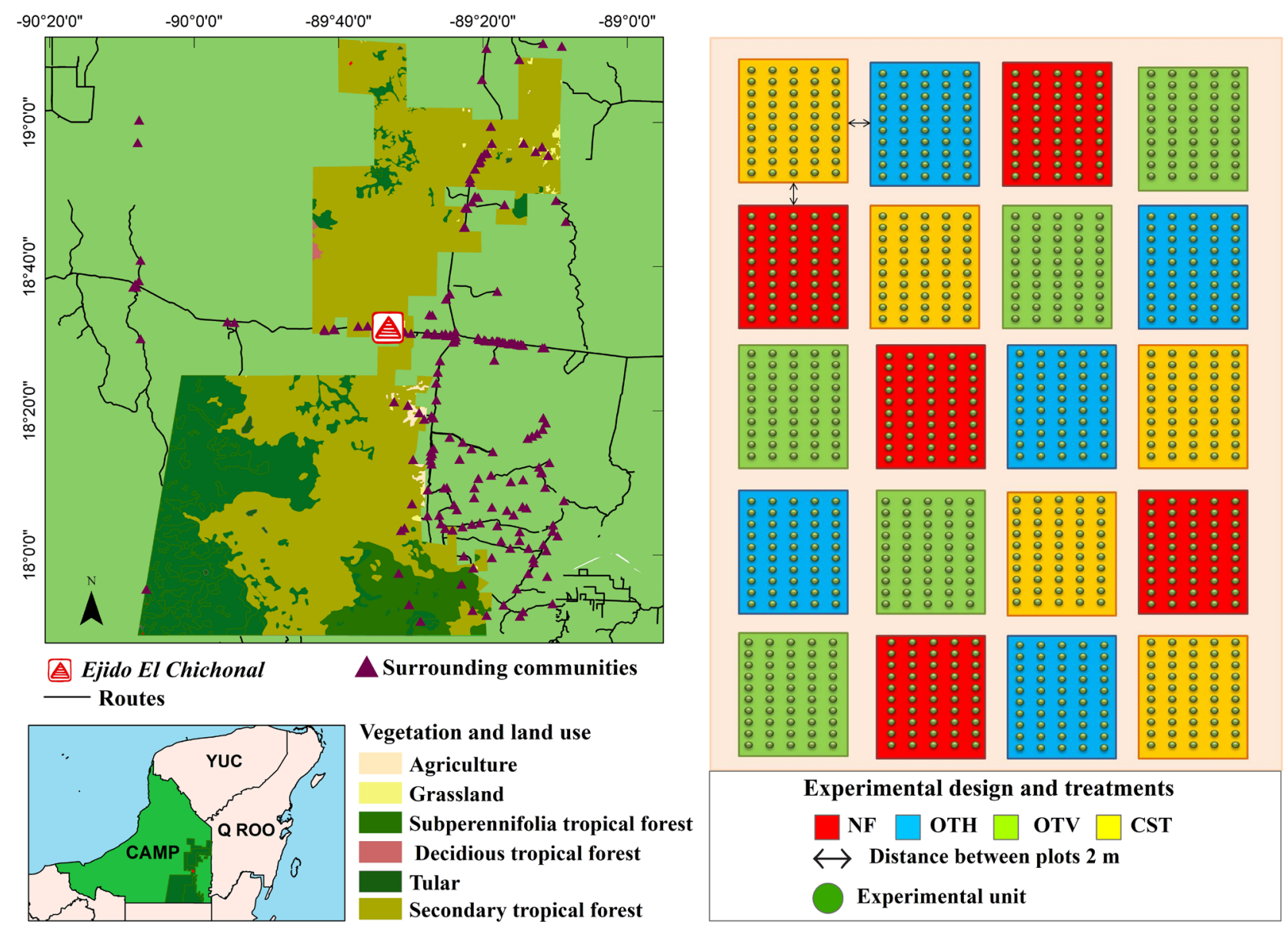

Figure 1. Site description, experimental design and treatments of organic and chemical agriculture systems of green tomato in Calakmul, Mexico. Red: NF = no fertilization, Blue: OTH = organic treatment with vermicompost and leachate, Green: OTV = organic treatment with vermicompost, and Yellow: CST = inorganic fertilizer treatment.

material of the soil is limestone rock, which is very poor in iron (Fe), silica, aluminum (Al), phosphorus $(\mathrm{P})$ and micronutrients (zinc and copper). The main soil type is leptosol rendzico, with a high content of organic matter and is alkaline [11]. It contains deciduous tropical forest vegetation with different structural appearances that reflect the variation in soil and other biophysical conditions [12]. A sub humid warm climate predominates $\left(\mathrm{AW}_{1}\right)$ according to Köppen classification scheme [13], and on the experimental period the mean temperature registered was $33^{\circ} \mathrm{C}$ and the mean rainfall precipitation was $45 \mathrm{~mm}$ [14].

\subsection{Site Selection}

The criteria used to select the crop planting site included the use of organic techniques by the farmer and a homogenous terrain with less than $5 \%$ of slope [15]. An agricultural plot with an area of $2400 \mathrm{~m}^{2}$ was chosen at a distance of 2 $\mathrm{km}$ from El Chichonal settlement. A year before our study, organic fertilization with vermicompost and tillage was applied to the soil for corn cultivation (Zea mays, L.), and the experimental site had been converted ten years before from 
conventional system to organic system production. Experimental units comprised plots of $25 \mathrm{~m}^{2}$. A two-meter-wide alley on each side separated each plot and ditches with a depth of $20 \mathrm{~cm}$ were dug around each plot to avoid the possibility of any effect caused by the contiguous treatment. All the experimental units were irrigated with plastic hoses and the plants were watered every 7 days. At the beginning the study, the physicochemical characteristics of the soil on the experimental site was determined and the initial values were: $11.05 \%$ of organic matter (OM), $0.55 \%$ of nitrogen $(\mathrm{N}), 7.47 \mathrm{pH}, 19.80 \mathrm{mg} \cdot \mathrm{kg}^{-1}$ of phosphorus $(\mathrm{P})$, $0.45 \mathrm{cmol} \cdot \mathrm{kg}^{-1}$ of potassium (K), $0.14 \mathrm{dS} \cdot \mathrm{m}^{-1}$ electrical conductivity (EC), 48.78 $\mathrm{cmol} \cdot \mathrm{kg}^{-1}$ cation exchange capacity (CEC), and texture was $40.30 \%$ Sand, $31.70 \%$ Clay, $28.00 \%$ Silt, and $0.98 \mathrm{~g} \cdot \mathrm{mL}^{-1}$ bulk density (BD).

\subsection{Preparation of Organic Fertilizer}

The organic fertilizer used was obtained from compost prepared using $40 \%$ corn stubble ( $Z$. mays), 40\% Taiwan grass (Pennisetum purpureum, Schumacher), and 20\% Arnica leaves (Thitonia diversifolia, Hemsl). These materials were obtained on the farm and crushed with a Koltler hammer mill (2500 rpm and 14 HP) and mixed in a 1:1 proportion with dry sheep dung (Ovis aries, L.). The mixture was then composted for one month on a concrete bed and subsequently inoculated with $3 \mathrm{~kg}$ of red earthworms (Lumbricus rubellus, Hoffmeister), approximately 1500 red earthworms, in the substrate. The substrate was maintained around $70 \%$ to $80 \%$ of humidity with water irrigation, until vermicompost was formed through the transformation of the organic matter by the action of the microorganisms present in the digestive tract of worms. Simultaneously, during vermicompost formation, leachates were collected by runoff from the floor of the composter, in which a plastic tube was connected to a tank of 500 liters. Finally, samples of vermicompost and leachate were collected for chemical analysis (Table 1).

\subsection{Experimental Design and Treatments}

The tomato crop was sown in January 2015 and harvested in April 2015. A Westar seed of green tomato was used (variety "rendidora"). The seeds were sown in 5 -cm-deep holes spaced $50 \mathrm{~cm}$ between them in each row. The distance between rows was $100 \mathrm{~cm}$; ten seeds per hole were initially sown following the farmer's agricultural technique. Subsequently, the best plants were selected, leaving 5 plants per hole when they had their first 5 true leaves in average and a mean height of $15 \mathrm{~cm}$. Twenty experimental plots $(5 \times 5 \mathrm{~m}$ each one $)$ were established. Each plot had 50 holes. A fully randomized block design was used, utilizing the slight $(<5 \%)$ slope of the land as a blocking criterion [16]. The following treatments with five repetitions were tested: a) control, without fertilizer application (NF); b) application of $13,000 \mathrm{~kg} \cdot \mathrm{ha}^{-1}$ of organic compost (vermicompost) equivalent to $160 \mathrm{~kg} \cdot \mathrm{N} \cdot \mathrm{ha}^{-1}(\mathrm{OTV})$; c) application of vermicompost and leachate 
Table 1. Chemical characteristics of the organic fertilizer used on the tomato cultivation.

\begin{tabular}{ccccccc}
\hline Component & $\mathrm{EC}$ & $\mathrm{pH}$ & $\mathrm{OM}$ & $\mathrm{N}$ & $\mathrm{P}$ & $\mathrm{K}$ \\
\hline Vermicompost & -- & -- & 30.96 & 2.05 & 616.50 & 28.96 \\
Leachate & 13.63 & 8.80 & -- & -- & 20.80 & 0.65 \\
\hline
\end{tabular}

$\mathrm{EC}=$ Electrical conductivity $\left(\mathrm{dS} \cdot \mathrm{m}^{-1}\right), \mathrm{OM}=$ Organic Matter (\%), $\mathrm{N}=$ Total nitrogen (\%), $\mathrm{P}=$ Available Phosphorus $\left(\mathrm{mg} \cdot \mathrm{kg}^{-1}\right), \mathrm{K}=$ Potassium $\left(\mathrm{cmol} \cdot \mathrm{kg}^{-1}\right) ;--$ Not available.

at $20 \mathrm{~L} \cdot \mathrm{ha}^{-1}(\mathrm{OTH})$ and d) application of $600 \mathrm{~kg} \cdot \mathrm{ha}^{-1}$ of chemical (inorganic) fertilizer containing $\mathrm{N}$, equivalent to $160 \mathrm{~kg} \cdot \mathrm{N} \cdot \mathrm{ha}^{-1}(\mathrm{CST})$ (Figure 1).

Fertilizer application and crop maintenance were carried out following Gûemes-Guillen et al., [17] recommendations, included in the green tomato growing guide prepared by National Research Institute of Forestry, Agriculture and Livestock (Instituto Nacional de Investigaciones Forestales, Agrícolas y Pecuarias-INIFAP). Vermicompost was applied manually in each plant at 20 days of growth, and leachate was prepared as liquid fertilizer by dilution of 1 liter of leachate in 20 liters of water, and then was sprayed with a backpack spray pump at the same time that vermicompost was applied. Pest control was achieved by applying Bacillum ${ }^{\infty}$ at $125 \mathrm{~mL} \cdot \mathrm{ha}^{-1}$ to the parcels under the organic treatments, and Falvus ${ }^{\circledR}$ was applied at $30 \mathrm{~g} \cdot \mathrm{ha}^{-1}$ to the inorganic treatment. The control treatment (NF) had no experienced pest management to avoid a confused effect due to the application of agrochemicals.

\subsection{Arbuscular Mycorrhizal (AM) Fungi Analysis}

AM fungi identification and morphologic analysis was conducted on soil samples that were randomly collected from the experimental plots. The quantification of spores and species diversity were analyzed in soil samples that were collected at a depth of $15 \mathrm{~cm}$. The fine roots were taken, at the end of the crop cycle, at $15 \mathrm{~cm}$ depth and the soil was washed in a sieve with running water to obtain only fine root samples. The fine root samples were dried at shade and placed in $100-\mathrm{mL}$ jars containing $5 \%$ acetic acid and stored at $4^{\circ} \mathrm{C}$ until analyzed in the laboratory.

For the laboratory analysis, spores present in 100 -g soil samples were extracted and counted by sieving method, decanting wet and sucrose gradient centrifugation, as suggested by Moreira et al., [18]. The spores were detached using a dissection needle under a Nikon SMZ800 stereoscopic microscope and were mounted in microscope slides with concentration polyvinyl alcohol solutions. Where necessary, the spores were dyed using Melzer's reagent. Taxonomic determination was performed based on observations of the form, size and coloration of the spores under a transmitted light microscope (100x) (Nikon Eclipse E600) and were collated with the guidelines proposed by Moreira et al., [18] and the International Culture Collection of Arbuscular Mycorrhizal Fungi (2014) (http://invam.caf.wvu.edu). 
To assess the similarity in AM fungal communities amongst treatments, a Jaccard's index was calculated and defined following formula:

$$
\text { Jaccard's index }=a /(a+b+c)
$$

where $a=$ number of AM fungal species common for two treatments, $b=$ number of AM fungal species present in the first treatments and absent in the second, and $c=$ number of AM fungal species absent in the first treatments and present in the second treatments [8] [18].

To estimate the percentage of AM fungi colonization fine roots, segments were examined under a transmitted light microscope (100x) (Nikon Eclipse E600). The presence or absence of structures such as hyphae, arbuscules and spores were determined in three equidistant visual fields for each segment [18]. Additionally, the length of hyphae ( $\mu \mathrm{m} / \mathrm{mm}$ root) was measured in each segment following the procedures described by Vega-Frutis and Guevara [19].

\subsection{Crop Yield}

Yield was recorded after fruit maturation on the plant. Fruits from 10 plants corresponding to each treatment were counted and weighed using a Torrey MFQ-40 electronic scale. Representative samples of each treatment were obtained, and the dry matter content (DM) was determined using a forced-air drying oven. Simultaneously, the equatorial and polar diameters of the fruits were measured using Vernier calipers. Fruit size was estimated based on the following formula:

$$
V=4 / 3\left(\pi^{\star} A^{\star} 2 B\right)
$$

where $A$ corresponds to the polar radius (height), $B$ corresponds to the equatorial radius (width and depth), and $\pi=3.1416$ [20].

\subsection{Crop Survival, Growth and Production}

Plant survival was determined based on the percentage of plants that died throughout the growing period. Plant height was measured with a tape measure from the base of each plant to the highest branch. Measurements were made upon application of the experimental treatments and after the growing period. Relative growth rate (RGR) was estimated using the following formula:

$$
\mathrm{RGR}=(\ln A 2-\ln A 1) /(t 2-t 1)
$$

where $A 2$ and $A 1$ represent plant height at times 2 (end of the growing period) and 1 (when were applied the experimental treatments); and $t 2$ and $t 1$ represent the days at the end $(t 2)$ of the growing period and the moment of the treatment application $(t 1)[21][22]$.

Above-ground and root biomass were also recorded throughout the total harvest of the plants. Above-ground biomass was quantified as stem, leaf, flowers and fruits production. Root biomass was obtained from the extraction of 20 $\mathrm{cm}$ long $\times 20 \mathrm{~cm}$ width $\times 15 \mathrm{~cm}$ depth soil cubes around each plant, helped with 
a shovel flat. The soil was removed manually with a brush and washed in a sieve with running water to obtain fresh roots. Fresh roots were dried at shade for 24 hours and weighted using a Torrey MFQ-40 digital scale. Later, to obtain dry matter content, roots were dried using a forced-air drying oven during 3 days at $50^{\circ} \mathrm{C}$, until constant weight were obtained.

\subsection{Soil Analysis}

During soil preparation to sown and at 50 days after starting the experiment, three soil samples per treatment were collected for physicochemical analysis. We used a representative random sampling with $95 \%$ confidence interval (CI) to collect the soil samples, it were taken at $20 \mathrm{~cm}$ from the tomato plant stem and a depth of $15 \mathrm{~cm}$. The collected soil was sieved through a $5-\mathrm{mm}$ sieve and then dried in the shade at room temperature. The samples were then sent to the laboratory to determine available phosphorus (P) by Olsen's method, organic matter (OM) was determined by Walkley-Black method, soil $\mathrm{pH}$ was measured in water (2:1 ratio) soil:water suspension, for total nitrogen $(\mathrm{N})$ determination samples was digested and quantified by titration according to method of micro-Kjeldahl, potassium $(\mathrm{K})$ was determined by ammonium acetate $(1 \mathrm{~N}, \mathrm{pH} 7)$, electrical conductivity (EC) was measured in a 1:5 (soil:deionized water) soil solution with a conductivity meter, cation exchange capacity (CEC) was determined as the total exchangeable base and ammonium acetate $(1 \mathrm{~N}, \mathrm{pH} 7)$, soil texture (clay, sand and silt percentages) were determined using a 10-g subsample and the Bouyoucos hydrometer method, and bulk density (BD) was determined by test tube of the volume of the dry soil mass displaced, according to the Mexican Official Standard (Norma Oficial Mexicana) NOM-021-RECNAT-2000 [18] [23].

\subsection{Statistical Analysis}

Data on soil physicochemical variables (OM, $\mathrm{pH}, \mathrm{P}, \mathrm{N}, \mathrm{K}, \mathrm{EC}, \mathrm{CEC}$ and $\mathrm{BD}$ ), were analyzed through one-way analysis of variance. The data of crop yield (fruit weight and size) and production (plant survival, relative growth rate, above-ground and root biomass) were analyzed through a two way analysis of variance in a fully randomized block design and the means of treatments were tested with Tukey's range test [16] using the statistical software R 3.1.2 [24]. Data on AM fungi colonization (hyphae, length hyphae, arbuscules, spores in root, species diversity, and spores in soil) were analyzed using the Kruskal-Wallis test, and treatment medians were tested using the Wilcoxon test [25].

The spores data counts for each species of AM fungi and soil physicochemical variables $(\mathrm{P}, \mathrm{OM}, \mathrm{pH}, \mathrm{K}, \mathrm{EC}, \mathrm{BD}$, and silt), were correlated using a canonical correspondence analysis (CCA) performed with R software, using "vegan" package [26]. Soil physicochemical variables were tested for outliers (Cleveland dotplot), normality (histogram), homogeneity (conditional boxplot), relationships (pair plots using "psych" package [27]) and collinearity (Variance inflation 
factor using "car" package [28]) according to Zuur et al. [29].

\section{Results}

\subsection{Soil Arbuscular Mycorrhizal (AM) Fungi Diversity and Root Colonization}

Twenty-one species and 16 morphotypes of AM fungi were found. OTH treatment had the largest number of species and morphotypes (17 and 11, respectively), whereas CST registered fewer species and morphotypes (7 and 4, respectively) (Figure 2).

The genera Glomus and Acaulospora were best represented in all treatments. With inorganic fertilization a reduced diversity of AM fungi in the soil was found; whereas organic fertilizer increased the AM fungi diversity, mainly by the presence of Claroideoglomus sp., Septoglomus sp., Ambispora sp., Gigaspora sp., Archaeospora sp., and Racocetra sp. (Figure 3). Also, with organic fertilization the following OTV-associated species and morphotypes were found: Acaulospora sp. 1, Ambispora sp., Claroideoglomus sp., and Glomus sp. 6. The species and morphospecies associated with OTH treatment were: Claroideoglomus claroideum, Claroideoglomus luteum, Funneliformis coronatum, Glomus sp. 5, Racocetra sp., Acaulospora denticulata and Archaeospora sp. Only Acaulospora rehmii was uniquely found in the NF treatment, and no unique species was found with CST treatment (Figure 2). Six species common to all treatments included the following: Funneliformis geosporum, Glomus glomerulatum, Rhizophagus intraradices, Glomus macrocarpum, and two Glomus sp. (Figure 2).

The effect of organic agricultural system on the presence of mycorrhizal interaction with the fine roots of tomato plants differed significantly $(p<0.05)$ between treatments. Plants subjected to organic agricultural system exhibited a higher percentage of total colonization $(p=0.03)$, vesicles $(p=0.02)$, arbuscules $(p=0.03)$ (Figure 4(a)) and length of hyphae $(\mu \mathrm{m} / \mathrm{mm}$ root) $(p=0.02)$ (Figure 4(b)); compared with unfertilized plants. And the percentage of colonization by vesicles and arbuscules was significantly higher $(p<0.05)$ in the OTV and OTH treatments compared with conventional agricultural system (CST).

No significant differences were observed between the treatments in respect to number of species $(p=0.50)$ and number of spores (in $100 \mathrm{~g}$ ) present in the soil $(p=0.65)$ (Figure 4(b)). But, the Jaccard index of similarity (Table 2) indicated that organic treatments had more AM fungal species in common than no fertilization or inorganic fertilization (CST). Nevertheless, there were significant differences in the diversity of AM fungal species.

\subsection{Physicochemical Soil Characteristics and AM Fungi Species Relation}

The relationship between soil physicochemical variables and the axis that resulted from the canonical correspondence analysis (CCA) are shown in Table 3 and Figure 5. The first component CCA1 was mainly explained by $\mathrm{K}(-0.740)$ 

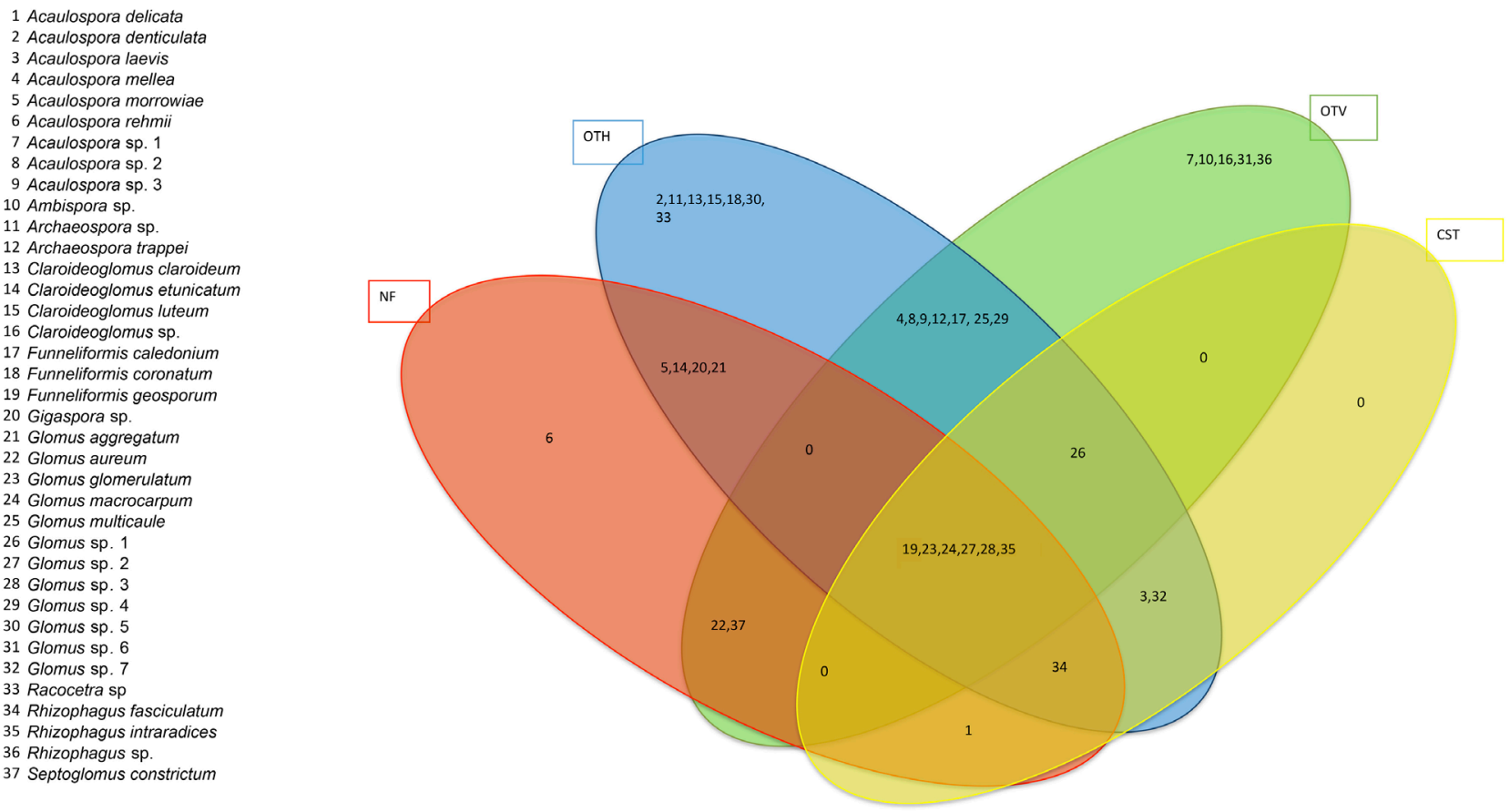

Figure 2. Species and morphotypes of Arbuscular Mycorrhizal fungi present on the soil in organic and conventional agricultural systems of green tomato $(P$. ixocarpa) cultivation. Red: $\mathrm{NF}=$ no fertilization, Blue: $\mathrm{OTH}=$ organic treatment with vermicompost and leachate, Green: OTV = organic treatment with vermicompost, and Yellow: CST = inorganic fertilizer treatment.

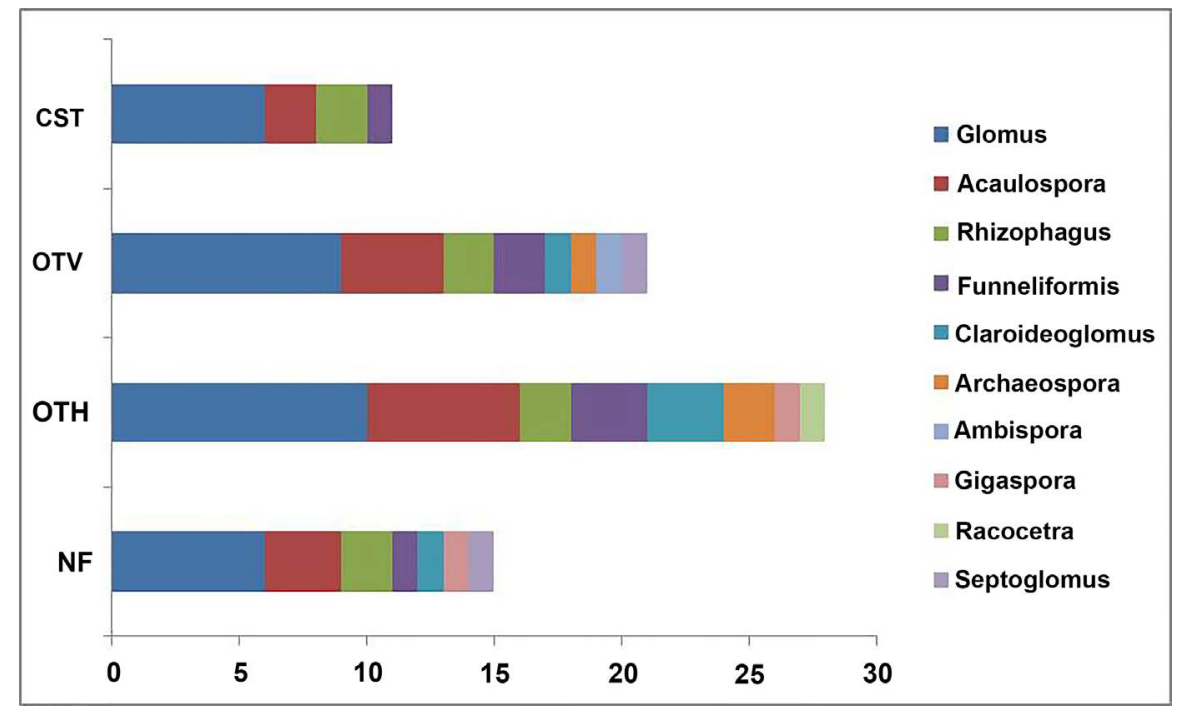

Figure 3. Number of species for genera of arbuscular mycorrhizal fungi present in the soil with four treatments for green tomato $(P$. ixocarpa) cultivation. NF $=$ no fertilization, $\mathrm{OTH}=$ organic treatment with vermicompost and leachate, OTV $=$ organic treatment with vermicompost, CST = inorganic fertilizer treatment.

meaning that lowers concentration of $\mathrm{K}$ promoted greater AM fungi diversity. On the other hand, variables that explained the maximum variance in CCA2 component were EC (0.792), BD (0.547), P (0.542) and they were positively related (Table 3 ). 


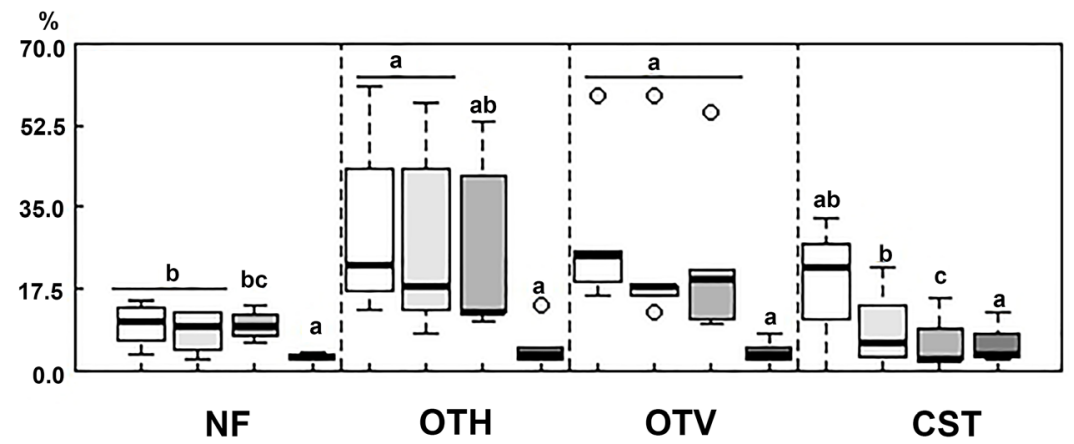

(a)

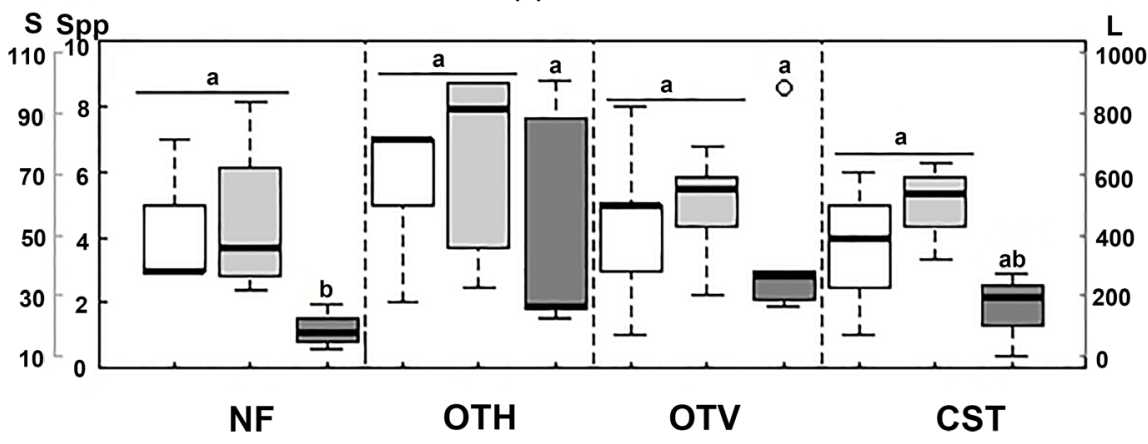

(b)

Figure 4. Effect of organic and conventional agricultural system on the AM fungi root colonization on green tomato ( $P$. ixocarpa) plants, and their effect on the number of fungi species and spores present in the soil. $\mathrm{NF}=$ no fertilization, $\mathrm{OTH}=$ organic treatment with vermicompost and leachate, OTV = organic treatment with vermicompost and CST = inorganic fertilizer treatment. (a) Root colonization; white: total (\%); light grey: vesicles (\%); grey: arbuscules (\%); and dark grey: spores (\%). (b) White: species (Spp, number) present in soil; light grey: spores (S, number) present in soil; and grey: length (l) of hyphae $(\mu \mathrm{m} / \mathrm{mm})$ in the roots. Kruskal-Wallis test; ${ }^{\text {abc }}$ different letters on the bar of the same color indicate significant $(p<0.05)$ differences; -: median, $\top: 1$ st and $3^{\text {rd }}$ quartiles; outlayers.

Table 2. Jaccard's index values of AM fungi diversity associated of the soil on organic and conventional agricultural systems of green tomato plants.

\begin{tabular}{cccc}
\hline Treatments & NF & OTH & OTV \\
\hline OTH & 0.30 & -- & -- \\
OTV & 0.29 & 0.40 & -- \\
CST & 0.44 & 0.34 & 0.28
\end{tabular}

$\mathrm{NF}=$ no fertilization, $\mathrm{OTH}=$ organic treatment with vermicompost and leachate, OTV = organic treatment with vermicompost and CST $=$ inorganic fertilizer treatment.

Silt was significantly correlated with the presence of AM fungi in the soil. K and EC showed a negative relation whit AM fungi diversity, in contrast with the silt (Table 4).

CCA showed that several AM fungi species were related negatively with the P, silt, $\mathrm{pH}, \mathrm{OM}$ and $\mathrm{BD}$, with independence of the treatments used (Figure 5). The 
Table 3. Canonical correspondence analysis of the soil physicochemical characteristic effects in AM fungi diversity considering all tomato cultivation treatments.

\begin{tabular}{cccccccc}
\hline Variable & CCA1 & CCA2 & CCA3 & CCA4 & CCA5 & CCA6 \\
\hline P $\left(\mathrm{mg} \cdot \mathrm{kg}^{-1}\right)$ & 0.450 & 0.545 & -0.135 & -0.651 & 0.124 & 0.164 \\
OM $(\%)$ & 0.298 & 0.181 & -0.245 & -0.482 & 0.530 & 0.532 \\
$\mathrm{pH}$ & 0.464 & 0.426 & 0.127 & -0.579 & -0.266 & -0.013 \\
$\mathrm{~K}\left(\mathrm{cmol} \cdot \mathrm{kg}^{-1}\right)$ & -0.741 & 0.072 & 0.045 & -0.113 & -0.508 & 0.396 \\
EC (dS.m $\left.{ }^{-1}\right)$ & -0.086 & 0.790 & -0.384 & -0.298 & -0.218 & -0.226 \\
BD $\left(\mathrm{g} \cdot \mathrm{mL}^{-1}\right)$ & 0.022 & 0.551 & 0.138 & 0.521 & 0.627 & -0.071 \\
Silt $(\%)$ & 0.680 & 0.484 & -0.210 & -0.466 & -0.174 & 0.104 \\
\hline
\end{tabular}

$\mathrm{P}=$ available phosphorus, $\mathrm{OM}=$ organic matter $\mathrm{K}=$ potassium, $\mathrm{EC}=$ electrical conductivity and $\mathrm{BD}=$ bulk density.

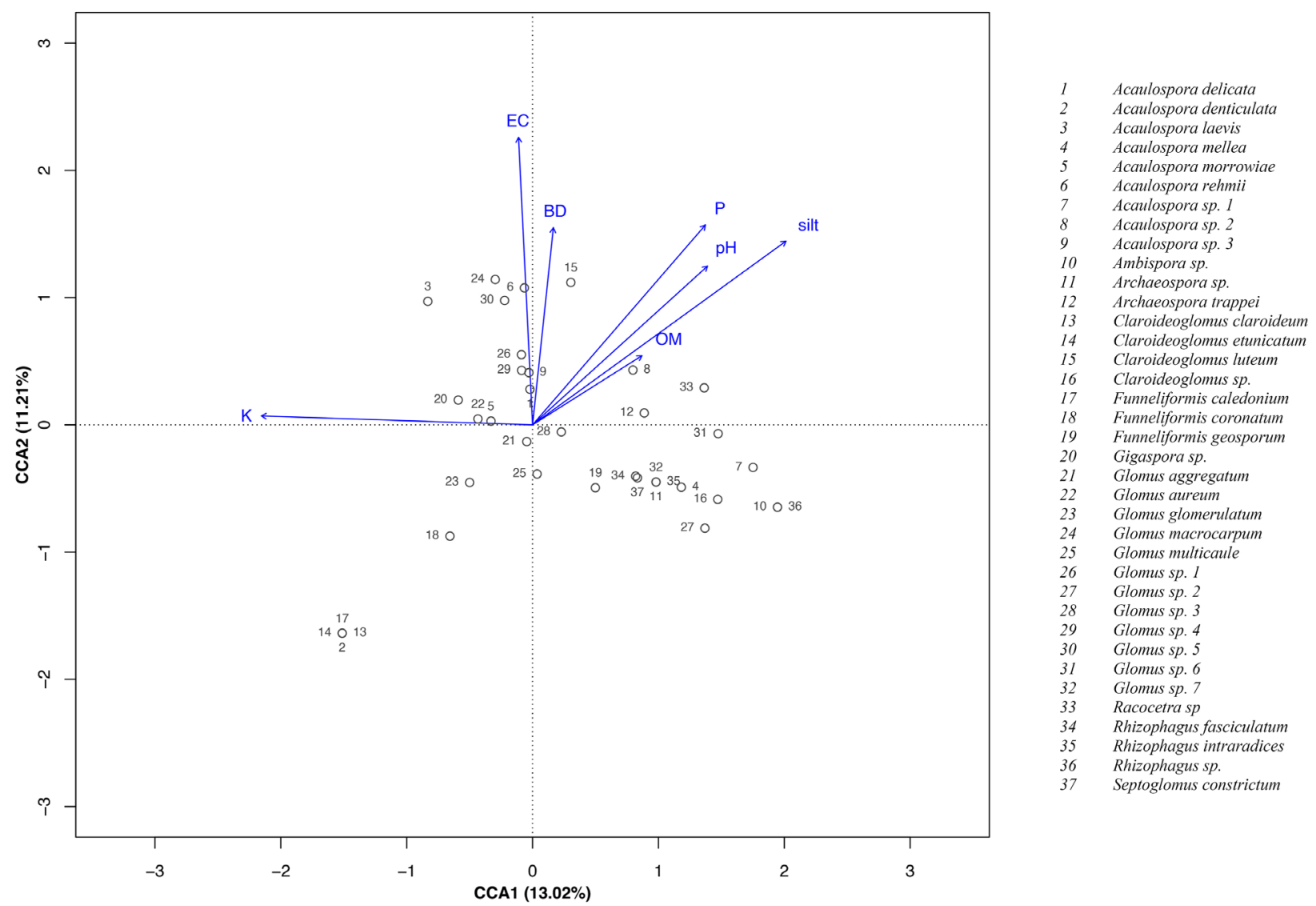

Figure 5. Canonical correlation analysis (CCA) showed the relationship between AM fungi species and physicochemical soil characteristics, under organic and conventional agricultural system of green tomato cultivation. Blue: $\mathrm{P}\left(\mathrm{mg}^{\mathrm{kg}} \mathrm{kg}^{-1}\right), \mathrm{K}\left(\mathrm{cmol} \cdot \mathrm{kg}^{-1}\right), \mathrm{OM}$ (\%), $\mathrm{pH}\left(\mathrm{H}_{2} \mathrm{O}\right), \mathrm{EC}\left(\mathrm{dS} \cdot \mathrm{m}^{-1}\right), \mathrm{BD}\left(\mathrm{g} \cdot \mathrm{mL}^{-1}\right)$, silt (\%). Gray: AM fungi species.

total variation value of the data was 3.86, the sum of all canonical eigenvalues was 2.09 , all seven explanatory variables explained $54 \%$ of the total variation in the data and the first two (canonical) eigenvalues were CCA1: 0.50 and CCA2: 0.43 . The first two canonical axes explained $24 \%$ of the variation that was related with the soil variables. 
Table 4. Canonical correspondence coefficients of the first two ordination axes showing the main contribution of the physicochemical characteristics on the tomato cultivation.

\begin{tabular}{ccccc}
\hline Variable & CCA1 & CCA2 & $R^{2}$ & $p$ value \\
\hline $\mathrm{P}\left(\mathrm{mg} \cdot \mathrm{kg}^{-1}\right)$ & 0.0658 & 0.752 & 0.477 & 0.074 \\
$\mathrm{OM}(\%)$ & 0.847 & 0.530 & 0.115 & 0.626 \\
$\mathrm{pH}$ & 0.744 & 0.667 & 0.383 & 0.142 \\
$\mathrm{~K}\left(\mathrm{cmol} \cdot \mathrm{kg}^{-1}\right)$ & -0.999 & 0.032 & 0.510 & $0.037^{\star}$ \\
$\mathrm{EC}\left(\mathrm{dS} \cdot \mathrm{m}^{-1}\right)$ & -0.049 & 0.998 & 0.561 & $0.023^{*}$ \\
$\mathrm{BD}\left(\mathrm{g} \cdot \mathrm{mL}^{-1}\right)$ & 0.106 & 0.994 & 0.266 & 0.295 \\
Silt $(\%)$ & 0.812 & 0.582 & 0.674 & $0.015^{\star}$ \\
\hline
\end{tabular}

$\mathrm{P}=$ available phosphorus, $\mathrm{OM}=$ organic Mater, $\mathrm{K}=$ potassium, $\mathrm{EC}=$ electrical conductivity and $\mathrm{BD}=$ bulk density. ${ }^{\star} p_{\alpha}<0.05$.

\subsection{Development and Yield of Tomato Fruits}

No significant differences were found between treatments with respect to total number of fruits $(p=0.47)$, number of mature fruits $(p=0.11)$, weight of mature fruits $(p=0.28)$, equatorial diameter $(p=0.33)$, polar diameter $(p=0.40)$ or fruit size $(p=0.39)$ (Table 5).

\subsection{Mortality, Growth and Plant Biomass}

Plant mortality was $18.8 \%$ to $22.6 \%$ and did not differ significantly between treatments $(p=0.95)$. Although final plant growth was not significantly influenced by treatment $(p=0.95)$, differences in the relative growth rate (RGR) ( $p=$ $0.03)$ were observed according to treatment. OTV presented a higher RGR $(10.47 \mathrm{~cm})$ with respect to OTH and NF and was similar to CST treatment $(8.18$ cm) (Table 6).

No significant differences in total above-ground and root biomass were found ( $P=0.07$ and $P=0.77$, respectively) between treatments at the end of the crop cycle.

\subsection{Soil Physicochemical Characteristics}

The soil predominantly comprised clay and loam. The OM, pH, P, N, and $\mathrm{K}$ soil content, and the EC, CEC and $\mathrm{BD}$ were similar $(P>0.05)$ in all experimental plots (Table 7).

\section{Discussion}

\subsection{Soil Arbuscular Mycorrhizal (AM) Fungi Diversity and Root Colonization}

AM fungi are present in the soil and colonize plant roots of cultivated plants. They increase the physicochemical quality of the soil, stabilize soil micro aggregates and improve the mobilization and transformation of nutrients [30]. In addition, AM fungi promote biota interactions in the rhizosphere [31]; the type of 
Table 5. Effect of organic and conventional agricultural system on mean yield and development of green tomato ( $P$. ixocarpa) crop.

\begin{tabular}{|c|c|c|c|c|c|c|c|}
\hline \multirow{2}{*}{ Variables } & \multicolumn{4}{|c|}{ Treatments } & \multirow[b]{2}{*}{$F_{3,12}$} & \multirow[b]{2}{*}{ S.E. } & \multirow[b]{2}{*}{$p$ value } \\
\hline & NF & OTH & OTV & CST & & & \\
\hline Total fruit (number) & 57.33 & 53.19 & 55.83 & 69.29 & 0.87 & 10.54 & 0.47 \\
\hline Mature fruit (number) & 14.30 & 11.78 & 17.08 & 23.09 & 2.30 & 4.52 & 0.11 \\
\hline Fruit yield (g/plant) ${ }^{1}$ & 14.81 & 12.59 & 17.29 & 21.48 & 1.36 & 4.90 & 0.28 \\
\hline Equatorial diameter $(\mathrm{cm})$ & 2.69 & 2.79 & 2.83 & 2.85 & 1.20 & 0.09 & 0.33 \\
\hline Polar diameter $(\mathrm{cm})$ & 2.33 & 2.36 & 2.46 & 2.43 & 1.04 & 0.08 & 0.40 \\
\hline Size $\left(\mathrm{cm}^{3}\right)$ & 9.47 & 10.27 & 11.04 & 11.02 & 0.98 & 1.05 & 0.39 \\
\hline
\end{tabular}

$\mathrm{NF}=$ no fertilization, $\mathrm{OTH}=$ organic treatment with vermicompost and leachate, $\mathrm{OTV}=$ organic treatment with vermicompost and CST $=$ inorganic fertilizer treatment. $F$ : degrees of freedom of the origins of variance. S.E.: Standard error of the mean differences, $\left(p_{\alpha}<0.05\right),{ }^{1}$ Dry weight.

Table 6. Effect of organic and conventional agricultural system in plant mortality, plant height, relative growth rate and biomass production of green tomato ( $P$. ixocarpa) crop.

\begin{tabular}{ccccccc}
\hline \multirow{2}{*}{ Variables } & NF & OTH & OTV & CST & S.E. & $p$ value \\
\cline { 2 - 7 } & 22.62 & 18.84 & 20.76 & 20.08 & 6.71 & 0.95 \\
\hline Mortality (\%) & 36.22 & 35.72 & 37.64 & 37.39 & 3.84 & 0.95 \\
Height (cm) & $7.49^{\mathrm{b}}$ & $7.52^{\mathrm{b}}$ & $10.47^{\mathrm{a}}$ & $8.18^{\mathrm{ab}}$ & 1.62 & 0.03 \\
RGR (cm) & 186.73 & 212.52 & 235.75 & 341.18 & 56.95 & 0.07 \\
${ }^{1}$ Aerial biomass (gr) & 41.32 & 50.86 & 54.47 & 45.48 & 13.37 & 0.77 \\
${ }^{1}$ Root biomass (gr) & &
\end{tabular}

$\mathrm{NF}=$ no fertilization, $\mathrm{OTH}=$ organic treatment with vermicompost and leachate, $\mathrm{OTV}=$ organic treatment with vermicompost, $\mathrm{CST}=$ inorganic fertilizer treatment. S.E.: Standard error of the mean differences $\left(\mathrm{P}_{\alpha}<\right.$ 0.05). RGR $=$ Relative Growth Rate of 43 days. ${ }^{1}$ mean dry weight; ${ }^{\text {abc }}$ Values in rows followed by the same letter are not significantly different $(P<0.05)$.

Table 7. The physicochemical characteristics of the soil on organic and conventional agricultural systems of green tomato plants.

\begin{tabular}{ccccccc}
\hline \multirow{2}{*}{ Variable } & \multicolumn{7}{c}{ Treatments } \\
\cline { 2 - 7 } & $\mathrm{NF}$ & OTH & OTV & CST & S.E. & $P$ value \\
\hline OM (\%) & 11.45 & 10.08 & 11.02 & 9.12 & 1.30 & 0.388 \\
$\mathrm{pH}\left(\mathrm{H}_{2} \mathrm{O}\right)$ & 7.90 & 7.83 & 8.08 & 7.80 & 0.30 & 0.831 \\
$\mathrm{P}\left(\mathrm{mg} \cdot \mathrm{kg}^{-1}\right)$ & 16.77 & 13.60 & 16.77 & 7.96 & 2.76 & 0.051 \\
$\mathrm{~N}(\%)$ & 0.57 & 0.52 & 0.55 & 0.45 & 0.06 & 0.351 \\
$\mathrm{~K}\left(\mathrm{cmol} \cdot \mathrm{kg}^{-1}\right)$ & 0.49 & 0.56 & 0.50 & 0.46 & 0.48 & 0.896 \\
EC $\left(\mathrm{dS} \cdot \mathrm{m}^{-1}\right)$ & 0.17 & 0.14 & 0.15 & 0.13 & 0.02 & 0.448 \\
$\mathrm{CEC}\left(\mathrm{cmol} \cdot \mathrm{kg}^{-1}\right)$ & 47.19 & 48.62 & 44.71 & 54.12 & 2.66 & 0.057 \\
Sand (\%) & 31.70 & 27.90 & 30.20 & 20.03 & 0.11 & 0.474 \\
Clay $(\%)$ & 36.30 & 43.30 & 33.80 & 55.30 & 7.52 & 0.112 \\
Silt $(\%)$ & 32.00 & 28.80 & 36.00 & 24.66 & 0.06 & 0.098 \\
BD (g.mL $\left.{ }^{-1}\right)$ & 0.56 & 0.54 & 0.55 & 0.52 & 0.11 & 0.985 \\
\hline
\end{tabular}

$\mathrm{NF}=$ no fertilization, $\mathrm{OTH}=$ organic treatment with vermicompost and leachate, OTV $=$ organic treatment with vermicompost, and CST = inorganic fertilization treatment. S.E.: Standard error of the mean differences. $\left(P_{\alpha}<0.05\right) . \mathrm{OM}=$ organic matter, $\mathrm{P}=$ available phosphorus, $\mathrm{N}=$ total nitrogen, $\mathrm{K}=$ potassium, $\mathrm{EC}=$ electrical conductivity, $\mathrm{CEC}=$ cation exchange capacity and $\mathrm{BD}=$ bulk density. 
organic fertilizer used, influences the diversity of AM taxa in soils under organic agriculture. The use of compost in organic fertilization promotes a greater AM fungi species [32] [33] [34].

The favorable impact of organic fertilizer application on the soil's microorganism community, especially on the AM fungi community represents a potential short-term additional benefit [8] [35]. The number of species of AM fungi have been reported for other agroecosystems under organic farming and is similar to the findings in this study [32]. However, as already mentioned, the application of organic fertilizers favors a greater diversity and richness of AM fungi species in the soil, whereas the application of inorganic fertilizers negatively affects diversity [8] [34] [35] [36] [37], as the conventional agriculture affect the viability and growth of some taxa in the rhizosphere [8] [10] [38] [39]. These changes are also observed in short-cycle crops, as in this study with green tomato, where the application of inorganic chemicals (CST) reduced the number of species of AM fungi.

The greater AM fungi abundance of the genera Glomus (Glomus glomerulatum and Glomus macrocarpum) and Acaulospora (Acaulospora delicata) in the treatments is due to differences in fungal strategies regarding to the use of host carbon sources under different physicochemical soil conditions [8]. Consequently, the genus Acaulospora is commonly observed in agricultural fields; similarly, the genus Glomus has been recorded in disturbed conditions because it can colonize roots and produce fungal structures in less time when compared with other genera [40] [41]. These genera have been found in various crops under both organic and inorganic systems [42], and in this study was not the exception (Figure 3). However, the abundance of Funneliformis geosporum, which was associated with CST, might reflect a greater ability of this species to tolerate changes in the soil nutrients under conventional agriculture; furthermore, this species might have a cost-benefit advantage in favoring crops under conditions of low soil P concentrations [36] [37]. However, when organic fertilization is applied (OTH, OTV), the organic matter and $\mathrm{P}$ increase together with AM fungi diversity, [37] leading to the presence of the genus Claroideoglomus spp., as well as the other species that were uniquely found in these treatments, such as Acaulospora mella, Archaeospora trappei, and Glomus multicaule and the genera Ambispora spp. and Racocetra spp. (Figure 2). This finding might indicate that these taxa are more sensitive to chemical management and respond favorably to the greater soil nutrient availability mostly $\mathrm{P}$ and $\mathrm{MO}$, resulting from the use of organic agricultural system, such as vermicompost [36] [37]; that could help to explain the similarity in species composition on organic treatments with Jaccard index showed in AM fungal community. In addition, fertilization with vermicompost promotes greater colonization and the formation of fungal structures (vesicles and arbuscules) in plant roots (Figure 4(a)) [36] [38] [43], and stimulates the growth of fine roots [44], thus allowing the plant to explore a greater area and to have greater interaction and contact sur- 
face with AM fungi [4] [35].

\subsection{Physicochemical Soil Characteristics and AM Fungi Diversity Relation}

The CCA showed a relation between physicochemical soil characteristics and AM fungi spores' diversity. K, CE and silt were the environmental factors related to AM fungi community composition. Most species were not positively associated with elevated $\mathrm{P}, \mathrm{pH}, \mathrm{OM}$ and silt concentrations. However, soil results showed these variables had higher values in organic treatments which suggested that diversity of AM fungi increased with the application of vermicompost and leachate and may benefit AM fungi development on soil and crop yield [10]. Avio, et al. [45] showed indirectly evidenced of AM fungi community structure may be affected by the conventional agriculture especially with the use of chemical fertilizers altering the concentration of soil mineral nutrients and physical characteristics. The organic management can promote higher AMF diversity and abundance than conventional agriculture, because it improves the quality of the soil [46] [47]. The CCA showed too that no particular AM fungi genera had an association with some soil variable but the rare species may be more sensitive to conventional management [47].

\subsection{Development and Yield of Tomato Fruits}

In the tropics and subtropics the lack of differences on tomato yield between organic and conventional agriculture is highly influenced by the precipitation, irrigation management, soil texture, the characteristic of organic input and the elapsed time after conversion from conventional systems to organic systems [2] [48]. The use of vermicompost favors the growth, quality and yield of leaves, fruits and grains in crops [14] [49] because it provides organic matter and micro- and macronutrients, and promotes soil fungi and bacterial activity [50]

In countries or geographical regions like Calakmul, where predominates 1000 - $1500 \mathrm{~mm}$ rain precipitation it is hardly to find differences in yield between organic and conventional systems [2]. Also, it has been observed that the irrigation management, as we supplied to tomato crop in this study, promotes lower yields on organic conditions. This is due to lower $\mathrm{N}$ use efficiency to produce fruits resulting in similar yield on organic treatments as respect to conventional system [51]. Other key factor that could influence these results and the quality of the fruit was the soil texture. In our study the soil was mainly composed of clay and loam, this fine textured soil decrease crop yield on organic system and it is consistently reported on other countries [2]. In addition, the conversion time from conventional to organic system could influence the lack of differences in fruit production in our study. As previously stated, the experimental site was converted from conventional system to organic system ten years before the present. In this respect, it has been observed that at least five years are required to equate the production of organic systems with a conventional system, and yet, after ten 
years organic farming only showed a trend to increase productivity [2]. Also, AM fungi community composition in soils of organic system could influence the crop production. It has been reported that some species of the genus Glomus [36] associated with organic treatments affect fruit production and maturation, resulting in a trend of lower total fruit production, number of mature fruits and fruit weight. On the other hand, our results differ from the findings of Carrubba et al. [52], they found a favorable effect of organic system compared to conventional systems regarding the performance of coriander (Coriandrum sativum, L.). Also, our data regarding fruit size and development differed from the findings reported by Singh et al. [50], who obtained better size and quality of strawberries (Fragaria $\times$ ananassa, Weston) using vermicompost compared to inorganic fertilization. These differences might be mediated by the environmental variations and soil physicochemical characteristics where was carried out the comparing studies [1] [3]. These studies were carried out on semi-arid environments and soils with coarse texture; in this conditions crops yield boost when received organic fertilization [2] [49] [50]. Although organic management did not result in greater fruit yield and development, it is important to note that the CST increases the dependency on external inputs, increase the cost of the cultivation and jeopardizes the development of sustainable agriculture [53]. In contrast, it is possible to maintain production similar to that achieved using inorganic fertilizers by using vermicompost. This organic fertilizer reduces external dependency, increases the integration of diverse agroecological components, and improve the health of the soil [53] [54]; promoting a sustainable agriculture development and maintaining soil fertility, one of the key ecosystem service of agroecological systems.

\subsection{Mortality, Growth and Plant Biomass}

Fertilization with vermicompost and leachate provides humic acids, which favor the absorption of micro- and macronutrients, control viral infections and dampen the effects of water stress, thereby reducing plant mortality [55] [56]. In addition, the application of organic fertilizers (OTV, OTH) increases the rate of plant growth, possibly due to the action of soil microorganisms that facilitate nutrient availability and AM fungi symbiosis, which in turn favor the absorption of essential minerals for plant growth [57] [58]. However, the use of organic fertilizers can result in low carbon assimilation in the plants due to some mycorrhizae of the genus Glomus, this results decrease in the reduced production of above-ground biomass compared with inorganic fertilizers [36], as observed in this study. The findings described here are consistent with findings reported for other crops, where greater production of above-ground biomass was observed for coriander (Coriandrum sativum L.), wheat (Triticum spp.) and medicinal plants in response to the application of inorganic fertilizers compared with organic fertilizers [4] [36] [52]. Despite lower above-ground biomass production, organic management with vermicompost favors the development and amount of 
root biomass in plants, perhaps due to a greater availability of soil nutrients [36] [44] mediated by AM fungi, through their mycelia network that improve P uptake on plant growth [8] [34].

\subsection{Soil Physicochemical Characteristics}

The management of arable land influences the mineralization of organic matter and the availability of macro and micronutrients [44] [59]. When soil is managed organically, the chemical characteristics of the soil and its nutrient quality and quantity remain unchanged [34]. But under medium and long-term organic management has been found an improved in chemical, physical and biological soil quality, increasing soil organic carbon, total $\mathrm{N}$ content and enhancing the soil organic matter, water holding capacity, aggregate stability and field-saturated hydraulic conductivity [54] [60]. However, management with agrochemicals reduces mineralization processes and lowers soil quality, thus affecting OM, N, P, and K contents [2] [61]. This effect was not clearly observed in the present study and the lack of the expected effects was most likely masked by the organic management that was applied to soil in the year before this study. In this regard, studies of longer duration are warranted to determine the effect of organic fertilization regime on the edaphic nutrient dynamics [62], physical quality of the soil [54] and the activity of microorganisms that affect nutrient availability [61].

\section{Conclusion}

On the organic agricultural systems, the use of vermicompost and lechate promotes a greater soil arbuscular mycorrhizal diversity, which interacts with the plant in the rhizosphere and results in higher plant growth rates with similar crop development and production that are obtained with conventional agriculture. Therefore, the use of vermicompost on organic agricultural systems can positively impact the production of green tomato in buffer zones of protected natural areas and this has implications for the future development of sustainable agriculture involving agroecological production systems.

\section{Acknowledgements}

The authors would like to thank the El Chichonal community, Calakmul, Campeche and the Institute of Ecology (Instituto de Ecología A.C); and the College of the Southern Border (El Colegio de la Frontera Sur) for facilitating the research and for technical support. Also thank the National Council for Science and Technology (Consejo Nacional de Ciencia y Tecnología, CONACYT) for a scholarship granted (588020) to the first author. We greatly appreciate the aid of Guadalupe Pérez Escobar, Miguel A. López Anaya and Jesús Carmona de la Torre for the chemical analyses, and Dra. Nelly Tremblay for the statistical analysis. 


\section{Conflicts of Interest}

The authors declare no conflicts of interest regarding the publication of this paper.

\section{References}

[1] Patil, S., Reidsma, P., Shah, P., Purushothaman, S. and Wolf, J. (2012) Comparing Conventional and Organic Agriculture in Karnataka, India: Where and When Can Organic Farming Be Sustainable? Land Use Policy, 37, 40-51. https://doi.org/10.1016/j.landusepol.2012.01.006

[2] Te Pas, C.M. and Rees, R.M. (2014) Analysis of Differences in Productivity, Profitability and Soil Fertility between Organic and Conventional Cropping Systems in the Tropics and Sub-Tropics. Journal of Integrative Agriculture, 13, 2299-2310. https://doi.org/10.1016/S2095-3119(14)60786-3

[3] Arnhold, S., Lindner, S., Lee, B., Martin, E., Kettering, J., Nguyen, T.T., et al. (2014) Conventional and Organic Farming: Soil Erosion and Conservation Potential for Row Crop Cultivation. Geoderma, 219-220, 89-105. https://doi.org/10.1016/j.geoderma.2013.12.023

[4] Khan, K., Pankaj, U., Verma, S.K., Gupta, A.K., Singh, R.P. and Verma, R.K. (2015) Bio-Inoculants and Vermicompost Influence on Yield, Quality of Andrographis paniculata and Soil Properties. Industrial Crops and Products, 70, 404-409. https://doi.org/10.1016/j.indcrop.2015.03.066

[5] González-Rosales, G., Nieto, A., Murillo-Amador, B., Villavicencio, E., Hernández-Medina, J. and Guerrero-Medrano, Z. (2012) Guía técnica para la producción de lombricomposta. Centro de Investigaciones Biológicas del Noroeste SC, editor. Baja California Sur, México, 153 p.

[6] Doan, T.T., Henry-des-Tureaux, T., Rumpel, C., Janeau, J.-L. and Jouquet, P. (2015) Impact of Compost, Vermicompost and Biochar on Soil Fertility, Maize Yield and Soil Erosion in Northern Vietnam: A Three Year Mesocosm Experiment. Science of the Total Environment, 514, 147-154. https://doi.org/10.1016/j.scitotenv.2015.02.005

[7] Alayón-Gamboa, J. (2010) Los huertos familiares en Calakmul: Diversidad y Contribución. FomixCampeche, 4, 7-11.

[8] Gianinazzi, S., Gollotte, A., Binet, M.-N., van Tuinen, D., Redecker, D. and Wipf, D. (2010) Agroecology: The Key Role of Arbuscular Mycorrhizas in Ecosystem Services. Mycorrhiza, 20, 519-530. https://doi.org/10.1007/s00572-010-0333-3

[9] Mbuthia, L.W., Acosta-Martínez, V., DeBryun, J., Schaeffer, S., Tyler, D., Odoi, E., et al. (2015) Long Term Tillage, Cover Crop and Fertilization Effects on Microbial Community Structure, Activity: Implications for Soil Quality. Soil Biology and Biochemistry, 89, 24-34. https://doi.org/10.1016/j.soilbio.2015.06.016

[10] Qin, H., Lu, K., Strong, P.J., Xu, Q., Wu, Q., Xu, Z., et al. (2015) Long-Term Fertilizer Application Effects on the Soil, Root Arbuscular Mycorrhizal Fungi and Community Composition in Rotation Agriculture. Applied Soil Ecology, 89, 35-43. https://doi.org/10.1016/j.apsoil.2015.01.008

[11] Pérez-Salicrup, D. (2004) Forest Types and Their Implications. In: Turner II, B.L., Geoghegan, J. and Foster, D.R., Eds., Integrated Land-Change Science and Tropical Deforestation in the Southern Yucatán Final frontiers, Oxford University Press, Oxford, 63-80. 
[12] Turner, B.L.I., Cortina-Villar, S., Foster, D., Geoghegan, J. and Keys, E. (2001) Deforestation in the Southern Yucatán Peninsular Region: An Integrative Approach. Forest Ecology and Management, 154, 343-370. https://doi.org/10.1016/S0378-1127(01)00508-4

[13] INE (1999) Programa de Manejo de la Reserva de la Biosfera Calakmul. México DF.

[14] CONAGUA (2015) Reporte del Clima en México. Delegación Miguel Hidalgo, México DF.

[15] Morón-Ríos, A. and Alayón-Gamboa, J. (2014) Productividad del cultivo de chile jalapeño (Capsicum anuum L.) con manejo orgánico o convencional en Calakmul, Campeche, México. Avances en Investigación Agropecuari, 18, 35-40.

[16] Gómez, K. and Gómez, A. (1983) Statistical Procedures for Agricultural Research. 2nd Edition, John Wiley \& Sons, Hoboken, 630 p.

[17] Gûemes-Guillen, M.J., Palacios-Álvarez, A., Ramírez-Rojas, S., García-Pérez, F., Salazar-Pedroza, A. and Inoue, K. (2001) Guía para cultivar tomate de cáscara en el estado de morelos. INIFAP Centro de investigación regional del centro campo experimental "Zacatepec" Zacatepec, Morelos, 19 p.

[18] Moreira, F., Huising, E.J. and Bignell, D.E. (2012) Manual de biología de suelos tropicales. Instituto Nacional de Ecología, México, 337 p.

[19] Vega-Frutis, R. and Guevara, R. (2009) Different Arbuscular Mycorrhizal Interactions in Male and Female Plants of Wild Carica papaya L. Plant Soil, 322, 65-76. https://doi.org/10.1007/s11104-009-9903-6

[20] Izadi, H., Kamgar, S., Raufat, M. and Samsami, S. (2014) Mass and Volume Modeling of Tomato Based on Physical Characteristics. Scientific Journal of Crop Science, 3, $1-8$.

[21] Villar, R., Ruiz-Robleto, J., Quero, J.L., Poorter, H., Valladares, F. and Marañón, T. (2008) Tasas de crecimiento en especies leñosas: aspectos funcionales e implicaciones ecológicas. In: Egraf, S.A., Ed., Ecología del bosque mediterráneo en un mundo cambiante, Ministerio de Medio Ambiente, España, 193-230.

[22] Torres-Degró, A. (2011) Tasas de crecimiento poblacional (r): Una mirada desde el modelo matemático lineal, geométrico y exponencial. CIDE Digit, 2, 142-160.

http://soph.md.rcm.upr.edu/demo/index.php/cide-digital/publicaciones\%5Cnhttp:/ /soph.md.rcm.upr.edu/demo/images/CIDEdigital/vo2no1/CIDEvo2no1-Arnaldo Torres Degro-Tasa crecimiento poblacional.pdf

[23] Salgado-García, S., Palma-López, D., Lagunes-Espinoza, J. and Castelán-Estrada, M. (2006) Manual para el muestreo de suelos plantas y aguas e interpretación de análisis. Colegio de Postgraduados, Campus Tabasco-ISPROTAB. H. Cárdenas, Tabasco, $90 \mathrm{p}$.

[24] R Version 3.12. (2014) "Pumpkin Helmet". Package Agricolae: Statistical Procedures for Agricultural Research y Copyright (C) The R Foundation for Statistical.

[25] Carles M. Cuadras (2014) Nuevos métodos de análisis multivariante. Carles M. Cuadras, Barcelona, $304 \mathrm{p}$.

[26] Oksanen, A.J., Blanchet, F.G., Friendly, M., Kindt, R., Legendre, P., Mcglinn, D., et al. (2017) Package "Vegan" Community Ecology.

[27] Revelle, M.W. (2011) Package "Psych". 1-250.

[28] Fox, J., Weisberg, S., Adler, D., Bates, D., Baud-bovy, G., Ellison, S., et al. (2016) Package "Car". 167.

[29] Zuur, A.F., Ieno, E.N. and Elphick, C.S. (2009) A Protocol for Data Exploration to 
Avoid Common Statistical Problems. Methods in Ecology and Evolution, 1, 3-14. https://doi.org/10.1111/j.2041-210X.2009.00001.x

[30] Palm, C., Blanco-Canqui, H., DeClerck, F., Gatere, L. and Grace, P. (2013) Conservation Agriculture and Ecosystem Services: An Overview. Agriculture, Ecosystems \& Environment, 187, 87-105. http://linkinghub.elsevier.com/retrieve/pii/S0167880913003502

[31] Cardoso, I.M. and Kuyper, T.W. (2006) Mycorrhizas and Tropical Soil Fertility. Agriculture, Ecosystems \& Environment, 116, 72-84. https://doi.org/10.1016/j.agee.2006.03.011

[32] Douds, D.D. and Millner, P.D. (1999) Biodiversity of Arbuscular Mycorrhizal Fungi in Agroecosystems. Agriculture, Ecosystems \& Environment, 74, 77-93. https://doi.org/10.1016/S0167-8809(99)00031-6

[33] Gosling, P., Hodge, A., Goodlass, G. and Bending, G. (2006) Arbuscular Mycorrhizal Fungi and Organic Farming. Agriculture, Ecosystems \& Environment, 113, 17-35. https://doi.org/10.1016/j.agee.2005.09.009

[34] Verbruggen, E., Röling, W., Gamper, H., Kowalchuk, G., Verhoef, H. and van der Heijden, M. (2010) Positive Effects of Organic Farming on Below-Ground Mutualists: Large-Scale Comparison of Mycorrhizal Fungal Communities in Agricultural Soils. New Phytologist, 186, 968-979. https://doi.org/10.1111/j.1469-8137.2010.03230.x

[35] Lazcano, C., Gómez-Brandón, M., Revilla, P. and Domínguez, J. (2013) Short-Term Effects of Organic and Inorganic Fertilizers on Soil Microbial Community Structure and Function. Biology and Fertility of Soils, 49, 723-733.

http://link.springer.com/10.1007/s00374-012-0761-7 https://doi.org/10.1007/s00374-012-0761-7

[36] Dai, M., Hamel, C., Bainard, L.D., Arnaud, M.St., Grant, C.A., Lupwayi, N.Z., et al. (2014) Negative and Positive Contributions of Arbuscular Mycorrhizal Fungal Taxa to Wheat Production and Nutrient Uptake Efficiency in Organic and Conventional Systems in the Canadian Prairie. Soil Biology and Biochemistry, 74, 156-166. http://www.sciencedirect.com/science/article/pii/S0038071714001059 https://doi.org/10.1016/j.soilbio.2014.03.016

[37] Schneider, K.D., Lynch, D.H., Dunfield, K., Khosla, K., Jansa, J. and Voroney, R.P. (2015) Farm System Management Affects Community Structure of Arbuscular Mycorrhizal Fungi. Applied Soil Ecology, 96, 192-200. http://www.sciencedirect.com/science/article/pii/S0929139315300512 https://doi.org/10.1016/j.apsoil.2015.07.015

[38] Druille, M., Omacini, M., Golluscio, R. and Cabello, M.N. (2013) Arbuscular Mycorrhizal Fungi Are Directly and Indirectly Affected by Glyphosate Application. Applied Soil Ecology, 72, 143-149. https://doi.org/10.1016/j.apsoil.2013.06.011

[39] van Diepen, L.T.A., Entwistle, E.M. and Zak, D.R. (2013) Chronic Nitrogen Deposition and the Composition of Active Arbuscular Mycorrhizal Fungi. Applied Soil Ecology, 72, 62-68. https://doi.org/10.1016/j.apsoil.2013.05.012 http://www.sciencedirect.com/science/article/pii/S0929139313001431

[40] Hart, M.M. and Reader, R.J. (2002) Taxonomic Basis for Variation in the Colonization Strategy of Arbuscular Mycorrhizal Fungi. New Phytologist, 153, 335-344. https://doi.org/10.1046/j.0028-646X.2001.00312.x

[41] Chagnon, P.-L., Bradley, R.L., Maherali, H. and Klironomos, J.N. (2013) A Trait-Based Framework to Understand Life History of Mycorrhizal Fungi. Trends 
in Plant Science, 18, 484-491. https://doi.org/10.1016/j.tplants.2013.05.001 http://www.sciencedirect.com/science/article/pii/S1360138513000885

[42] Jefwa, J.M., Okoth, S., Wachira, P., Karanja, N., Kahindi, J., Njuguini, S., et al. (2012) Impact of Land Use Types and Farming Practices on Occurrence of Arbuscular Mycorrhizal Fungi (AMF) Taita-Taveta District in Kenya. Agriculture, Ecosystems \& Environment, 157, 32-39. https://doi.org/10.1016/j.agee.2012.04.009 http://www.sciencedirect.com/science/article/pii/S016788091200151X

[43] Meyer, A.H., Wooldridge, J. and Dames, J.F. (2015) Effect of Conventional and Organic Orchard Floor Management Practices on Arbuscular Mycorrhizal Fungi in a “Cripp's Pink"/M7 Apple Orchard Soil. Agriculture, Ecosystems \& Environment, 213, 114-120. http://linkinghub.elsevier.com/retrieve/pii/S0167880915300402 https://doi.org/10.1016/j.agee.2015.07.026

[44] Cavender, N.D., Atiyeh, R.M. and Knee, M. (2003) Vermicompost Stimulates Mycorrhizal Colonization of Roots of Sorghum Bicolor at the Expense of Plant Growth. Pedobiologia, 47, 85-89. https://doi.org/10.1078/0031-4056-00172 http://linkinghub.elsevier.com/retrieve/pii/S0031405604701821

[45] Avio, L., Castaldini, M., Fabiani, A., Bedini, S., Sbrana, C., Turrini, A., et al. (2013) Impact of Nitrogen Fertilization and Soil Tillage on Arbuscular Mycorrhizal Fungal Communities in a Mediterranean Agroecosystem. Soil Biology and Biochemistry, 67, 285-294. http://www.sciencedirect.com/science/article/pii/S0038071713003064 https://doi.org/10.1016/j.soilbio.2013.09.005

[46] Gryndler, M., Hršelová, H., Cajthaml, T., Havránková, M., Řezáčová, V., Gryndlerová, H., et al. (2009) Influence of Soil Organic Matter Decomposition on Arbuscular Mycorrhizal Fungi in Terms of Asymbiotic Hyphal Growth and Root Colonization. Mycorrhiza, 19, 255-266. http://link.springer.com/10.1007/s00572-008-0217-y https://doi.org/10.1007/s00572-008-0217-y

[47] Hassan, S.E.D., Liu, A., Bittman, S., Forge, T.A., Hunt, D.E., Hijri, M., et al. (2013) Impact of 12-Year Field Treatments with Organic and Inorganic Fertilizers on Crop Productivity and Mycorrhizal Community Structure. Biology and Fertility of Soils, 49, 1109-1121. http://link.springer.com/10.1007/s00374-013-0813-7 https://doi.org/10.1007/s00374-013-0813-7

[48] Campiglia, E., Mancinelli, R., De Stefanis, E., Pucciarmati, S. and Radicetti, E. (2015) The Long-Term Effects of Conventional and Organic Cropping Systems, Tillage Managements and Weather Conditions on Yield and Grain Quality of Durum Wheat (Triticum durum Desf.) in the Mediterranean Environment of Central Italy. Field Crops Research, 176, 34-44.

http://linkinghub.elsevier.com/retrieve/pii/S0378429015000714

[49] Singh, R., Sharma, R.R., Kumar, S., Gupta, R.K. and Patil, R.T. (2008) Vermicompost Substitution Influences Growth, Physiological Disorders, Fruit Yield and Quality of Strawberry (Fragaria $\times$ ananassa Duch.). Bioresource Technology, 99, 8507-8511. http://www.sciencedirect.com/science/article/pii/S0960852408002599 https://doi.org/10.1016/j.biortech.2008.03.034

[50] Singh, R., Gupta, R.K., Patil, R.T., Sharma, R.R., Asrey, R., Kumar, A., et al. (2010) Sequential Foliar Application of Vermicompost Leachates Improves Marketable Fruit Yield and Quality of Strawberry (Fragaria $\times$ ananassa Duch.). Scientia Horticulturae, 124, 34-39. https://doi.org/10.1016/j.scienta.2009.12.002 http://www.sciencedirect.com/science/article/pii/S0304423809005196

[51] Seufert, V., Ramankutty, N. and Foley, J. (2012) Comparing the Yields of Organic and Conventional Agriculture. Nature, 485, 229-332. 
https://doi.org/10.1038/nature11069

[52] Carrubba, A. (2014) Organic and Chemical N Fertilization on Coriander (Coriandrum sativum L.) in a Mediterranean Environment. Industrial Crops and Products, 57, 174-187. http://www.sciencedirect.com/science/article/pii/S0926669014001642 https://doi.org/10.1016/j.indcrop.2014.03.030

[53] Koohafkan, P., Altieri, M. and Gimenez, E.H. (2012) Green Agriculture: Foundations for Biodiverse, Resilient and Productive Agricultural Systems. International Journal of Agricultural Sustainability, 10, 61-75. https://doi.org/10.1080/14735903.2011.610206

[54] Crittenden, S.J., Poot, N., Heinen, M., van Balen, D.J.M. and Pulleman, M.M. (2015) Soil Physical Quality in Contrasting Tillage Systems in Organic and Conventional Farming. Soil \& Tillage Research, 154, 136-144.

http://linkinghub.elsevier.com/retrieve/pii/S016719871500135X

https://doi.org/10.1016/j.still.2015.06.018

[55] Gutiérrez-Miceli, F.A., García-Gómez, R.C., Rincón Rosales, R., Abud-Archila, M., Cruz, M.J.G., et al. (2008) Formulation of a Liquid Fertilizer for Sorghum (Sorghum bicolor (L.) Moench) Using Vermicompost Leachate. Bioresource Technology, 99, 6174-6180. http://www.sciencedirect.com/science/article/pii/S0960852407010371 https://doi.org/10.1016/j.biortech.2007.12.043

[56] Yogev, A., Raviv, M., Kritzman, G., Hadar, Y., Cohen, R., Kirshner, B., et al. (2009) Suppression of Bacterial Canker of Tomato by Composts. Crop Protection, 28, 97-103. http://www.sciencedirect.com/science/article/pii/S0261219408001786 https://doi.org/10.1016/j.cropro.2008.09.003

[57] Arancon, N.Q., Edwards, C.A., Babenko, A., Cannon, J., Galvis, P. and Metzger, J.D. (2008) Influences of Vermicomposts, Produced by Earthworms and Microorganisms from Cattle Manure, Food Waste and Paper Waste, on the Germination, Growth and Flowering of Petunias in the Greenhouse. Applied Soil Ecology, 39, 91-99. http://www.sciencedirect.com/science/article/pii/S0929139307001679 https://doi.org/10.1016/j.apsoil.2007.11.010

[58] Baum, C., El-Tohamy, W. and Gruda, N. (2015) Increasing the Productivity and Product Quality of Vegetable Crops Using Arbuscular Mycorrhizal Fungi: A Review. Scientia Horticulturae, 187, 131-141.

http://www.sciencedirect.com/science/article/pii/S0304423815001211 https://doi.org/10.1016/j.scienta.2015.03.002

[59] Quinton, J.N., Govers, G., Van Oost, K. and Bardgett, R.D. (2010) The Impact of Agricultural Soil Erosion on Biogeochemical Cycling. Nature Geoscience, 3, 311-314. http://www.nature.com/doifinder/10.1038/ngeo838 https://doi.org/10.1038/ngeo838

[60] D’Hose, T., Cougnon, M., De Vliegher, A., Vandecasteele, B., Viaene, N., Cornelis, W., et al. (2014) The Positive Relationship between Soil Quality and Crop Production: A Case Study on the Effect of Farm Compost Application. Applied Soil Ecolo$g y, 75,189-198$. https://doi.org/10.1016/j.apsoil.2013.11.013

[61] Tian, W., Wang, L., Li, Y., Zhuang, K., Li, G., Zhang, J., et al. (2015) Responses of Microbial Activity, Abundance, and Community in Wheat Soil after Three Years of Heavy Fertilization with Manure-Based Compost and Inorganic Nitrogen. Agriculture, Ecosystems \& Environment, 213, 219-227.

http://linkinghub.elsevier.com/retrieve/pii/S0167880915300530

https://doi.org/10.1016/j.agee.2015.08.009 
[62] Bedada, W., Karltun, E., Lemenih, M. and Tolera, M. (2014) Long-Term Addition of Compost and NP Fertilizer Increases Crop Yield and Improves Soil Quality in Experiments on Smallholder Farms. Agriculture, Ecosystems \& Environment, 195, 193-201. http://linkinghub.elsevier.com/retrieve/pii/S0167880914003375 https://doi.org/10.1016/j.agee.2014.06.017 